\title{
Asymmetric Information Renders Minimum Wages Less Harmful
}

\author{
RONNIE SCHÖB \\ MARCEL THUM
}

CESIFO WORKING PAPER No. 2623

CATEGORY 4: LABOUR MARKETS

APRIL 2009

\footnotetext{
An electronic version of the paper may be downloaded

- from the SSRN website: Www.SSRN.com

- from the RePEc website: $\quad$ www.RePEc.org

- from the CESifo website: $\quad$ www.CESifo-group.org/wp
} 


\title{
Asymmetric Information Renders Minimum Wages Less Harmful
}

\begin{abstract}
We show that a minimum wage introduced in the presence of asymmetric information about worker productivities will lead to lower unemployment levels than predicted by the standard labour market model with heterogeneous labour and symmetric information.

JEL Code: J2, J3, H5, L5.

Keywords: minimum wages, unemployment, asymmetric information, labour market regulation.

Ronnie Schöb

Free University Berlin

School of Business \& Economics

Boltzmannstrasse 20

14195 Berlin

Germany

ronnie.schoeb@fu-berlin.de

Marcel Thum

Faculty of Business and Economics

TU Dresden

01062 Dresden

Germany

marcel.thum@tu-dresden.de
\end{abstract}

March 2009 


\section{Introduction}

The minimum wage is a costly redistributive tool when it causes unemployment among the least productive workers. Despite the clear-cut predictions from the standard labour market theory that minimum wages above market-clearing wage level cause unemployment, many cross country studies differ widely on the labour market effects of minimum wages. ${ }^{1}$ We argue that complementary regulatory measures in the labour market may influence the magnitude of minimum wage effects. Already existing distortions such as job protection can counteract the distortive effects of minimum wages. Job protection makes it more difficult for firms to exploit what they have learnt about workers' productivities and thus creates asymmetric information. When employers can only imperfectly distinguish ex ante between high- and low- ability workers, they are not able to pay different wages. This implies that they do not compare the marginal productivity of a low-ability worker with the minimum wage but the higher expected marginal productivity. This change in the firms' hiring pattern renders the minimum wage less harmful when complementary labour market policies are at work.

To develop the argument we set up a simple model with two types of labour that differ with respect to their abilities (or productivities). In the scenario with symmetric information, firms can observe individual abilities and pay wages accordingly. In the scenario with asymmetric information, firms cannot distinguish ability types and, therefore, have to pay a uniform wage. This set-up is similar to the framework chosen by Blumkin and Sadka (2005). Different to Blumkin and Sadka (2005) optimal taxation approach, however, we abstract from the possibility of workers to provide some costly signal about their respective productivities and focus on a positive analysis, asking whether existing complementary regulatory measures that change the informational framework in the labour market might render a minimum wage less harmful. Thereby, we show how the impact of a statutory minimum wage hinges on productivity differences and on the initial distribution of the workers' abilities.

The paper is organized as follows. In Section 2, we set up the model and describe the equilibrium with symmetric information. Section 3 introduces the asymmetric information

\footnotetext{
${ }^{1}$ See Neumark and Wascher (2008) for a comprehensive survey on the labour market impact of minimum wages.
} 
scenario. We compare the outcomes in the two scenarios with respect to employment in Section 4. Section 5 concludes.

\section{A standard labour market model with symmetric information}

There are two types of workers, low- and high-ability workers who are endowed with $q_{l}$ and $q_{h}$ efficiency units of labour $\left(q_{l}<q_{h}\right)$. The total number of workers is normalized to unity. The share of high-ability workers in the population is given by $h . L_{l}$ and $L_{h}$ denote actual employment of low- and high-ability workers, respectively.

Without loss of generality, we normalize the total number of firms to unity. High- and lowability workers are substitutes in the production process where each firm produces according to $f\left(q_{h} L_{h}+q_{l} L_{l}\right)$ with $f^{\prime}>0$ and $f^{\prime \prime}<0$. Different productivities are not due to differences in (observable) education but rather due to ex ante unobservable ability differences. All firms behave competitively and take the output price $p=1$ and the wage rates $w_{l}$ and $w_{h}$ for the low- and high-ability workers as given. Profit maximization yields the first-order conditions

$$
\frac{\partial \pi}{\partial L_{j}}=f^{\prime}\left(q_{h} L_{h}+q_{l} L_{l}\right) q_{j}-w_{j}=0 \quad \text { for } j=h, l,
$$

which define the labour demand for high- and low-ability workers. In equilibrium, all workers have to be paid at least the legal minimum wage $b\left(w_{j} \geq b, j=h, l\right)$. Depending on the magnitude of the minimum wage, we can distinguish four cases.

Case A: If the minimum wage is below $b_{s}^{\text {full }} \equiv f^{\prime}\left(q_{h} \cdot h+q_{l} \cdot(1-h)\right) q_{l}$, all workers will be employed and we have $L_{h}=h$ and $L_{l}=1-h$. This critical level above which a statutory minimum wage becomes binding depends on the productivities of both low- and high-ability workers and their respective shares. A larger share of high-ability workers reduces the marginal productivity of the last worker and thus the maximum non-binding minimum wage. Figure 1 depicts the outcome in the labour market with the share of the high-ability workers $h$ on the horizontal axis and the minimum wage $b$ on the vertical axis. All points below the declining $b_{s}^{\text {full }}$-curve are characterized by full employment (area A), all points above are associated with unemployment. The $b_{s}^{\text {full }}$-curve is downward sloping, i.e. the critical minimum wage will be lower the larger the fraction $h$ of high-ability workers. An increase in $h$ reduces marginal productivity as more efficiency units of labour are employed. This leads to 
lower employment levels for a given wage. As the wage for the low productivity workers cannot be adjusted downwards, they are the first to be laid off.

Case B: If the minimum wage is slightly above the $b_{s}^{\text {full }}$-curve, unemployment occurs but affects only low-ability workers up to the point where the last low-ability worker is laid off. In the interval $b_{s}^{\text {full }}<b \leq f^{\prime}\left(q_{h} \cdot h\right) q_{l} \equiv \underline{b}_{s}^{[1-h]}$, high-ability workers are fully employed, but there is unemployment among low-ability workers:

$$
L_{h}=h \text { and } 0<L_{l}=f^{\prime-1}\left(\frac{b}{q_{l}}\right) \frac{1}{q_{l}}-\frac{q_{h}}{q_{l}} \cdot h<1-h .
$$

Figure 1: Employment with symmetric information

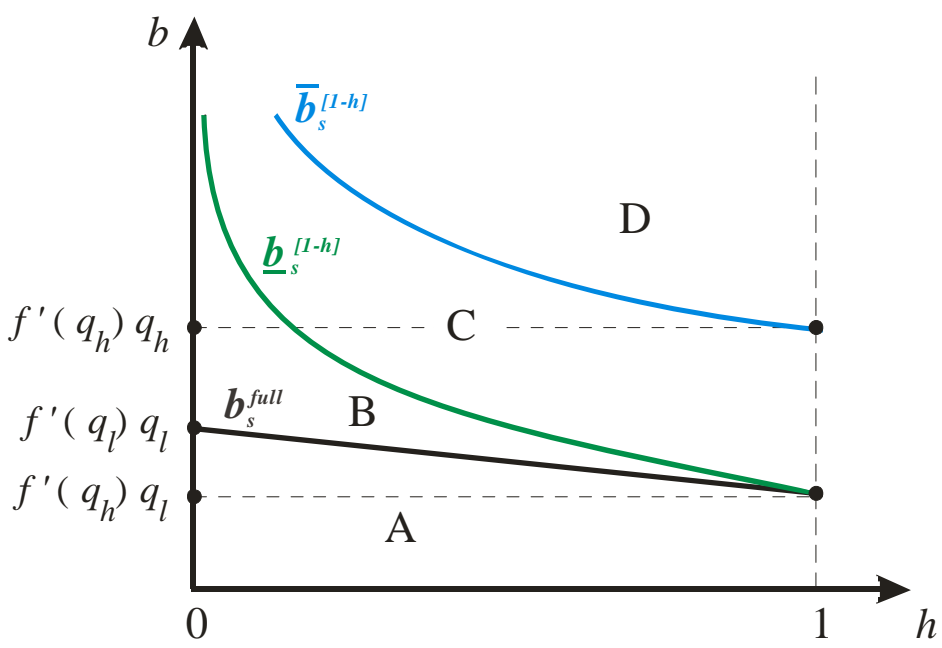

Case C: Above the $\underline{b}_{s}^{[1-h]}$-curve, the minimum wage becomes so high that no low-ability worker will be employed. As long as the marginal productivity of the last high-ability worker is above the minimum wage, the firm will not lay off this type of worker. Thus, within the range $\underline{b}_{s}^{[1-h]}<b \leq f^{\prime}\left(q_{h} \cdot h\right) q_{h} \equiv \bar{b}_{s}^{[1-h]}$, it pays to employ all high-ability workers but it is not profitable to hire any low-ability worker:

$$
L_{h}=h \text { and } L_{l}=0 .
$$

Case D: For $b \geq \bar{b}_{s}^{[1-h]}$, even the high-ability workers face unemployment. The employment levels fall to

$$
L_{h}=f^{\prime-1}\left(\frac{b}{q_{h}}\right) \frac{1}{q_{h}}<h \text { and } L_{l}=0 .
$$




\section{Asymmetric information}

Now we turn to the case of asymmetric information. Firms can only detect an individual's ability after having hired a new worker. Employment protection laws prevent firms from firing workers once they have learned about the productivities or from rewriting wage contracts. All firms decide simultaneously on the size of their workforce. From the point of view of an individual firm, the distribution of productivities follows a binomial distribution. As we are interested in the impact of pooling heterogeneous workers and not so much in the stochastic process itself, we facilitate the analysis by assuming that each firm is sufficiently large and gets a share of high-ability workers for sure. The average productivity amounts to $q_{a}=q_{h} h+q_{l}(1-h)$ and the representative firm maximizes $\pi=f\left(q_{a} L\right)-w L$ with respect to employment. The first-order condition immediately yields the labour demand $L=f^{\prime-1}\left(w / q_{a}\right) q_{a}^{-1}$. We define the minimum wage that just ensures full employment $(L=1)$ with asymmetric information as $b_{a} \equiv f^{\prime}\left(q_{a}\right) q_{a}$. For $b>b_{a}$, the minimum wage employment falls to

$$
L_{a}=f^{\prime-1}\left(\frac{b}{q_{a}}\right) \frac{1}{q_{a}} .
$$

\section{Comparing employment levels}

Do minimum wages generate the same unemployment patterns in the two informational scenarios? Comparing $b_{a}$ and $b_{s}^{\text {full }}$ yields $b_{a}=q_{a} / q_{l} \cdot b_{s}^{\text {full }}$ with $q_{a} / q_{l}>1$. Thus we have

Proposition 1. The level at which the minimum wage becomes harmful with asymmetric information always exceeds the respective level with symmetric information by the factor $q_{a} / q_{l}>1$.

It follows from Proposition 1 that, if the minimum wage does not cause unemployment with symmetric information, it will never cause unemployment with asymmetric information. If the minimum wage is so low that it does not even prevent the employment of the last low-ability worker, it also cannot distort the allocation of labour with asymmetric information. Moreover, if the minimum wage is between the marginal productivity of the last low-ability worker and the expected marginal productivity at full employment, firms have no incentive to hire low- 
ability workers in the symmetric information scenario but would still hire a worker when the individual ability is unknown.

A standard argument why the minimum wage may not be as harmful refers to monopsonistic structures in the labour market [Manning (2003)]. Proposition 1 provides an additional argument: asymmetric information has a softening effect on the detrimental impact of minimum wages in otherwise functioning labour markets because firms focus on expected marginal productivity rather than the lower marginal productivity of the low-ability type.

In Figure 2 we add the $b_{a}$-curve to the lines introduced in Figure 1. We can distinguish six different outcomes. Proposition 1 describes the outcomes in the areas $A, B_{1}$ and $C_{1}$. In area $A$ we have non-binding minimum wages in both scenarios. In areas $B_{1}$ and $C_{1}$, the minimum wage will destroy some $\left(B_{1}\right)$ or all jobs $\left(C_{1}\right)$ for low-ability workers with symmetric information while still ensuring full employment with asymmetric information.

Figure 2: Employment levels - symmetric vs. asymmetric information

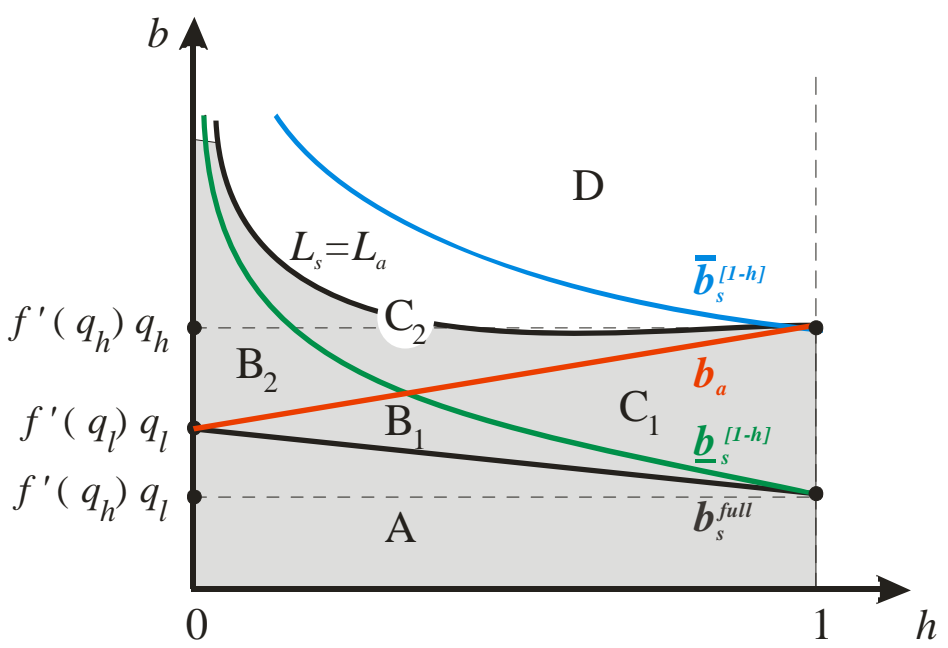

In Figure 2, we assume that $b_{a}$ is upward sloping, which is the case for $\partial b_{a} / \partial h=\left(q_{h}-q_{l}\right)\left(f^{\prime \prime}\left(q_{a}\right) q_{a}+f^{\prime}\left(q_{a}\right)\right)>0 .^{2}$ An increase in $h$ raises expected marginal productivity. This effect is not outweighed by the increase in efficiency units of labour so that the firms will hire more workers if $h$ increases. This is in contrast to the symmetric information scenario where an increase in $h$ always lowers marginal productivity of the lowability workers.

\footnotetext{
${ }^{2}$ This assumption, for instance, always holds for the Cobb-Douglas production technology.
} 
Proposition 2. With asymmetric information, raising the share of high-ability workers $h$ allows the government to raise the minimum wage without harming employment if $f^{\prime \prime}\left(q_{a}\right) q_{a}+f^{\prime}\left(q_{a}\right)>0$.

Unemployment occurs in both scenarios above the $b_{a}$-curve but employment will be higher in the asymmetric information scenario along the $b_{a}$-curve (and slightly above). Thus, the $L_{s}=L_{a}$-curve, on which employment levels (with $L<1$ ) are the same, must be in the areas $\mathrm{B}_{2}, \mathrm{C}_{2}$ and $\mathrm{D}$ in Figure 2. To determine the location of the $L_{s}=L_{a}$-curve, consider the following thought experiment. If the firms hire exactly $h$ workers in the asymmetric information scenario, marginal productivity will be $f^{\prime}\left(h q_{a}\right) q_{a}$. In the symmetric case, the marginal productivities amount to $f^{\prime}\left(q_{h} \cdot h\right) q_{l}$ and $f^{\prime}\left(q_{h} \cdot h\right) q_{h}$ on the $\underline{b}_{s}^{[1-h]}$-curve and the $\bar{b}_{s}^{[1-h]}$-curve, respectively. Along the two curves and in-between, employment also amounts to $h$. As employment falls monotonically with $b$ in the symmetric information scenario, the $L_{s}=L_{a}$-curve must be in area $C_{2}$, if $f^{\prime}\left(q_{h} \cdot h\right) q_{l}<f^{\prime}\left(h q_{a}\right) q_{a}<f^{\prime}\left(q_{h} \cdot h\right) q_{h}$. This is the case for $f^{\prime \prime}(x) x+f^{\prime}(x)>0$. In the alternative case $\quad\left(f^{\prime \prime}(x) x+f^{\prime}(x)<0\right)$, we get $f^{\prime}\left(h q_{a}\right) q_{a}>f^{\prime}\left(q_{l} \cdot h\right) q_{l}$, which implies that on the $\underline{b}_{s}^{[1-h]}$-curve employment is still higher with asymmetric information. Thus, for $f^{\prime \prime}(x) x+f^{\prime}(x)<0$, the $L_{s}=L_{a}$-curve must be located in area D.

Below the $L_{s}=L_{a}$-curve, employment is always larger in the asymmetric information scenario. ${ }^{3}$ For moderate minimum wages, which only affect the low-ability workers, asymmetric information renders a statutory minimum wage less harmful. Only with very high minimum wages, the economy may achieve higher employment levels when firms operate under symmetric information. Thus, the negative employment effects of a minimum wage can be alleviated in the presence of complementary regulatory measures such as job protection that de facto introduces asymmetric information about workers' abilities. Above the $L_{s}=L_{a}$ curve, the minimum wage is more harmful in the asymmetric information setting. This can be summarized in

\footnotetext{
${ }^{3}$ Along the $L_{s}=L_{a}$-curve, output is higher in the symmetric information scenario because only high-ability workers are employed. It is straightforward to show that the iso-output curve is also in area $C_{2}$ and below the $L_{s}=L_{a}$-curve.
} 
Proposition 3. If the minimum wage affects high-ability workers in the symmetric information scenario, asymmetric information renders the impact of a statutory minimum wage always more harmful for $f^{\prime \prime}(x) x+f^{\prime}(x)>0$.

\section{Conclusion}

The standard economic analysis shows that a minimum wage above the full employment wage for low-ability workers causes unemployment. Our analysis has shown that this may not be true in the presence of complementary regulatory measures such as job protection that affect the informational structure in the labour market. Generating asymmetric information forces firms to focus on average rather than marginal productivities when hiring workers. A statutory minimum wage below the average productivity at full employment allows the government to raise the wage of low-ability workers without distorting the labour market. High minimum wages, however, also cause unemployment with asymmetric information. Eventually, the existence of complementary policy measures becomes detrimental.

\section{References}

Blumkin, Tomer and Efraim Sadka (2005): "Compensation Policy and Optimal Income Taxation - The Case of Minimum Wage”, International Tax and Public Finance 12, 713722.

Manning, Alan (2003): Monopsony in Motion - Imperfect Competition in Labor Markets, Princeton University Press, Princeton, NJ.

Neumark, David and William Wascher (2008): Minimum Wages, MIT Press, Cambridge, MA. 


\section{CESifo Working Paper Series}

for full list see www.cesifo-group.org/wp

(address: Poschingerstr. 5, 81679 Munich, Germany, office@cesifo.de)

2561 Carsten Hefeker, Taxation, Corruption and the Exchange Rate Regime, February 2009

2562 Jiahua Che and Gerald Willmann, The Economics of a Multilateral Investment Agreement, February 2009

2563 Scott Alan Carson, Demographic, Residential, and Socioeconomic Effects on the Distribution of $19^{\text {th }}$ Century US White Statures, February 2009

2564 Philipp Harms, Oliver Lorz and Dieter Urban, Offshoring along the Production Chain, February 2009

2565 Patricia Apps, Ngo Van Long and Ray Rees, Optimal Piecewise Linear Income Taxation, February 2009

2566 John Whalley and Shunming Zhang, On the Arbitrariness of Consumption, February 2009

2567 Marie-Louise Leroux, Endogenous Differential Mortality, Non-Contractible Effort and Non Linear Taxation, March 2009

2568 Joanna Bęza-Bojanowska and Ronald MacDonald, The Behavioural Zloty/Euro Equilibrium Exchange Rate, March 2009

2569 Bart Cockx and Matteo Picchio, Are Short-Lived Jobs Stepping Stones to Long-Lasting Jobs?, March 2009

2570 David Card, Jochen Kluve and Andrea Weber, Active Labor Market Policy Evaluations: A Meta-analysis, March 2009

2571 Frederick van der Ploeg and Anthony J. Venables, Harnessing Windfall Revenues: Optimal Policies for Resource-Rich Developing Economies, March 2009

2572 Ondřej Schneider, Reforming Pensions in Europe: Economic Fundamentals and Political Factors, March 2009

2573 Jo Thori Lind, Karl Ove Moene and Fredrik Willumsen, Opium for the Masses? Conflict-Induced Narcotics Production in Afghanistan, March 2009

2574 Silvia Marchesi, Laura Sabani and Axel Dreher, Agency and Communication in IMF Conditional Lending: Theory and Empirical Evidence, March 2009

2575 Carlo Altavilla and Matteo Ciccarelli, The Effects of Monetary Policy on Unemployment Dynamics under Model Uncertainty - Evidence from the US and the Euro Area, March 2009 
2576 Falko Fecht, Kjell G. Nyborg and Jörg Rocholl, The Price of Liquidity: Bank Characteristics and Market Conditions, March 2009

2577 Giorgio Bellettini and Filippo Taddei, Real Estate Prices and the Importance of Bequest Taxation, March 2009

2578 Annette Bergemann and Regina T. Riphahn, Female Labor Supply and Parental Leave Benefits - The Causal Effect of Paying Higher Transfers for a Shorter Period of Time, March 2009

2579 Thomas Eichner and Rüdiger Pethig, EU-Type Carbon Emissions Trade and the Distributional Impact of Overlapping Emissions Taxes, March 2009

2580 Antonios Antypas, Guglielmo Maria Caporale, Nikolaos Kourogenis and Nikitas Pittis, Selectivity, Market Timing and the Morningstar Star-Rating System, March 2009

2581 António Afonso and Christophe Rault, Bootstrap Panel Granger-Causality between Government Budget and External Deficits for the EU, March 2009

2582 Bernd Süssmuth, Malte Heyne and Wolfgang Maennig, Induced Civic Pride and Integration, March 2009

2583 Martin Peitz and Markus Reisinger, Indirect Taxation in Vertical Oligopoly, March 2009

2584 Petra M. Geraats, Trends in Monetary Policy Transparency, March 2009

2585 Johannes Abeler, Armin Falk, Lorenz Götte and David Huffman, Reference Points and Effort Provision, March 2009

2586 Wolfram F. Richter, Taxing Education in Ramsey’s Tradition, March 2009

2587 Yin-Wong Cheung, Menzie D. Chinn and Eiji Fujii, China's Current Account and Exchange Rate, March 2009

2588 Alexander Haupt and Silke Uebelmesser, Voting on Labour-Market Integration and Education Policy when Citizens Differ in Mobility and Ability, March 2009

2589 Hans Jarle Kind, Marko Koethenbuerger and Guttorm Schjelderup, Should UtilityReducing Media Advertising be Taxed?, March 2009

2590 Alessandro Cigno, How to Avoid a Pension Crisis: A Question of Intelligent System Design, March 2009

2591 Helmut Lütkepohl and Fang Xu, The Role of the Log Transformation in Forecasting Economic Variables, March 2009

2592 Rainald Borck, Hyun-Ju Koh and Michael Pflüger, Inefficient Lock-in and Subsidy Competition, March 2009 
2593 Paolo M. Panteghini, On the Equivalence between Labor and Consumption Taxation, March 2009

2594 Bruno S. Frey, Economists in the PITS?, March 2009

2595 Natalie Chen and Dennis Novy, International Trade Integration: A Disaggregated Approach, March 2009

2596 Frédérique Bec and Christian Gollier, Term Structure and Cyclicity of Value-at-Risk: Consequences for the Solvency Capital Requirement, March 2009

2597 Carsten Eckel, International Trade and Retailing, March 2009

2598 Gianni De Nicolò and Iryna Ivaschenko, Global Liquidity, Risk Premiums and Growth Opportunities, March 2009

2599 Jay Pil Choi and Heiko Gerlach, International Antitrust Enforcement and Multi-Market Contact, March 2009

2600 Massimo Bordignon and Guido Tabellini, Moderating Political Extremism: Single Round vs Runoff Elections under Plurality Rule, April 2009

2601 Ana B. Ania and Andreas Wagener, The Open Method of Coordination (OMC) as an Evolutionary Learning Process, April 2009

2602 Simon Gächter, Daniele Nosenzo, Elke Renner and Martin Sefton, Sequential versus Simultaneous Contributions to Public Goods: Experimental Evidence, April 2009

2603 Philippe Jehiel and Andrew Lilico, Smoking Today and Stopping Tomorrow: A Limited Foresight Perspective, April 2009

2604 Andreas Knabe, Steffen Rätzel, Ronnie Schöb and Joachim Weimann, Dissatisfied with Life, but Having a Good Day: Time-Use and Well-Being of the Unemployed, April 2009

2605 David Bartolini and Raffaella Santolini, Fiscal Rules and the Opportunistic Behaviour of the Incumbent Politician: Evidence from Italian Municipalities, April 2009

2606 Erkki Koskela and Jan König, Can Profit Sharing Lower Flexible Outsourcing? A Note, April 2009

2607 Michel Beine, Frédéric Docquier and Çağlar Özden, Diasporas, April 2009

2608 Gerd Ronning and Hans Schneeweiss, Panel Regression with Random Noise, April 2009

2609 Adam S. Booij, Bernard M.S. van Praag and Gijs van de Kuilen, A Parametric Analysis of Prospect Theory's Functionals for the General Population, April 2009 
2610 Jeffrey R. Brown, Julia Lynn Coronado and Don Fullerton, Is Social Security Part of the Social Safety Net?, April 2009

2611 Ali Bayar and Bram Smeets, Economic, Political and Institutional Determinants of Budget Deficits in the European Union, April 2009

2612 Balázs Égert, The Impact of Monetary and Commodity Fundamentals, Macro News and Central Bank Communication on the Exchange Rate: Evidence from South Africa, April 2009

2613 Michael Melvin, Christian Saborowski, Michael Sager and Mark P. Taylor, Bank of England Interest Rate Announcements and the Foreign Exchange Market, April 2009

2614 Marie-Louise Leroux, Pierre Pestieau and Gregory Ponthiere, Should we Subsidize Longevity?, April 2009

2615 Ronald MacDonald, Lukas Menkhoff and Rafael R. Rebitzky, Exchange Rate Forecasters' Performance: Evidence of Skill?, April 2009

2616 Frederick van der Ploeg and Steven Poelhekke, The Volatility Curse: Revisiting the Paradox of Plenty, April 2009

2617 Axel Dreher, Peter Nunnenkamp, Hannes Öhler and Johannes Weisser, Acting Autonomously or Mimicking the State and Peers? A Panel Tobit Analysis of Financial Dependence and Aid Allocation by Swiss NGOs, April 2009

2618 Guglielmo Maria Caporale, Roman Matousek and Chris Stewart, Rating Assignments: Lessons from International Banks, April 2009

2619 Paul Belleflamme and Martin Peitz, Asymmetric Information and Overinvestment in Quality, April 2009

2620 Thomas Dohmen, Armin Falk, David Huffman and Uwe Sunde, Are Risk Aversion and Impatience Related to Cognitive Ability?, April 2009

2621 Yin-Wong Cheung and Xingwang Qian, The Empirics of China's Outward Direct Investment, April 2009

2622 Frédérique Bec and Christian Gollier, Assets Returns Volatility and Investment Horizon: The French Case, April 2009

2623 Ronnie Schöb and Marcel Thum, Asymmetric Information Renders Minimum Wages Less Harmful, April 2009 